\title{
Humanitarian Projects Development from Universidad del Zulia SIGHT Affinity Group
}

\section{Desarrollo de Proyectos Humanitarios desde el Grupo de Afinidad SIGHT de la Universidad del Zulia}

Luis Rodríguez ${ }^{1}$, Javier Hernández², Javier Peres ${ }^{3}$, José Viloria ${ }^{4}$, Laura Sánchez ${ }^{5}$, Henry Urdaneta ${ }^{6}$, Douglimar González ${ }^{7}$, Nardiz Mendoza ${ }^{8}$, Josimar Tello-Maita ${ }^{9}$, Andry Contreras ${ }^{10}$, Manuel Briceño ${ }^{11}$, Claudia Guevara ${ }^{12}$

Rodríguez, L; Hernández, J; Peres, J; Viloria, J; Sánchez, L; Urdaneta, H; González, D; Mendoza, N; Tello-Maita, J; Contreras, A; Briceño, M; Guevara, C. Humanitarian projects development from Universidad del Zulia sight affinity group. Tecnología en Marcha. Vol. 34, especial. Noviembre LAEDC 2021. Pág 56-61.

doi) https://doi.org/10.18845/tm.v34i6.5974

1 Rama Estudiantil IEEE. Universidad del Zulia. Maracaibo, Venezuela Email: lirodriguez@ieee.org

2 Rama Estudiantil IEEE. Universidad del Zulia. Maracaibo, Venezuela. Email: ing.jhernandezp@gmail.com

3 Rama Estudiantil IEEE. Universidad del Zulia. Maracaibo, Venezuela. Email: peresrjavier@gmail.com

4 Rama Estudiantil IEEE. Universidad del Zulia. Maracaibo, Venezuela. Email: joseviloria1996@gmail.com

5 Rama Estudiantil IEEE. Universidad del Zulia. Maracaibo, Venezuela. Email: laurasanchezsadl@gmail.com

6 Rama Estudiantil IEEE. Universidad del Zulia. Maracaibo, Venezuela. Email: urdanetah28@gmail.com

7 Rama Estudiantil IEEE. Universidad del Zulia. Maracaibo, Venezuela. Email: dougligv@gmail.com

8 Rama Estudiantil IEEE. Universidad del Zulia. Maracaibo, Venezuela. Email: nardizalberto@gmail.com

9 Universidad del Zulia, School of Electrical Engineering. Maracaibo, Venezuela. Email: jtello@fing.luz.edu.ve

10 Universidad del Zulia, School of Electrical Engineering. Maracaibo, Venezuela. Email: acontreras@fing.luz.edu.ve

11 Universidad del Zulia, School of Electrical Engineering. Maracaibo, Venezuela. Email: mbriceno@fing.luz.edu.ve

12 Chevron. Lechería, Venezuela. Email: claudiaguevara@chevron.com 


\title{
Keywords
}

Humanitarian projects; Universidad del Zulia; volunteering; quality of life; distance education; educational project; COVID-19.

\begin{abstract}
This work aims to divulge the volunteering experiences within humanitarian projects development from Universidad del Zulia SIGHT affinity group in Venezuela. At first, "Una mano por tu Facultad" project carried out in 2019 is described, which had the active participation of volunteers from the RE-IEEE-LUZ student branch and the SIGHT-LUZ affinity group and resulted in the recovery of twenty-six (26) classrooms and four (4) laboratories of the Faculty of Engineering. Furthermore, a new project is underway in response to COVID-19, which is focused on a distance education system using funds approved by the Humanitarian Activities Committee (HAC) and the Special Interest Group on Humanitarian Technology (SIGHT) of the Institute of Engineers Electrical and Electronic (IEEE). This group has the objective of bringing technologies-based solutions to problems existing in local communities in the Zulia State, Venezuela.
\end{abstract}

\section{Palabras clave}

Proyectos humanitarios; Universidad del Zulia; voluntariado; calidad de vida; educación a distancia; proyecto de educación; COVID-19.

\section{Resumen}

El trabajo presentado tiene la intención de divulgar las experiencias de voluntariado en el desarrollo de proyectos humanitarios desde el grupo de afinidad SIGHT de la Universidad del Zulia (LUZ) en Venezuela. En primer lugar, se describe el proyecto "Una Mano por tu facultad" llevado a cabo en el 2019, que contó con la participación activa de los voluntarios de la rama estudiantil RE-IEEE-LUZ y del grupo de afinidad SIGHT-LUZ y resultó en la recuperación de veintiséis (26) aulas y cuatro (4) laboratorios de la Facultad de Ingeniería. Además, un nuevo proyecto se encuentra en marcha en respuesta al COVID-19, enfocado en un sistema de educación a distancia utilizando fondos aprobados por el Comité de Actividades Humanitarias (HAC) y el Grupo de interés especial sobre tecnología humanitaria (SIGHT) del Instituto de Ingenieros Eléctricos y Electrónicos (IEEE). Este grupo busca aportar soluciones basadas en tecnologías a problemas existentes en comunidades locales del Estado Zulia, Venezuela.

\section{Introduction}

The Universidad del Zulia (LUZ) is an autonomous public university funded in 1891 at Maracaibo, Venezuela. It is one of the largest and most relevant universities form this country, with more than 70.000 students and 150 academic programs [1]. Since 1999 students and professors at the Electrical Engineering School of this institution have integrated the IEEE student branch (RE-IEEE-LUZ), being a non-profit organization with the mission of bringing its members closer to the industry through the organization of extracurricular activities joining important organizations from the industrial sector [2].

The Institute of Electrical and Electronics Engineers (IEEE), is the world's largest professional technical society dedicated to advancing technological innovation and excellence for the benefit of humanity. The student branches, chapters, and affinity groups from IEEE organize a large number of technical, non-technical, administrative and social activities, most of them free and open to the community. [3]. 
In 2019, the SIGHT-LUZ group was founded as an initiative of several members of the RE-IEEELUZ, who were already involved in community service projects paired with NGOs from the region. This proposal was also motivated by the humanitarian crisis that has taken place in recent years in Venezuela, with more than 4.5 million Venezuelans leaving the country and more than $90 \%$ of the population living with incomes that qualify as poverty [4].

Being LUZ a public institution, an important part of it depends on government funding to operate, and under current circumstances, this funding has been reduced to a historical minimum. Therefore, the members of the SIGHT-LUZ group have perceived this as an opportunity of implementing projects and programs that can contribute to the continuity of the academic activities carried out in the Electrical Engineering school, which is an essential area for the development of any country and industry.

Furthermore, the COVID-19 pandemic has affected the world in an unprecedented manner, and as such, HAC/SIGHT (Special Interest Group on Humanitarian Technology) is offering a Call for Proposals to support IEEE grassroots humanitarian technology and sustainable development projects that utilize technology to address the COVID-19. As a result, "Distance Education Program Adapted to COVID-19 for Universidad del Zulia" funding was approved, and the project is ongoing.

\section{A helping hand for your faculty}

"Una Mano por tu Facultad" was the name given to this project involving all student and professors community from the Engineering Faculty of Universidad del Zulia [5]. In 2019, this was the 4th opportunity to engage in this project with the help of different departments from the Engineering Faculty and lead by RE-IEEE-LUZ and the SIGHT-LUZ Affinity Group. It was a nonprofit initiative focused on recovering, maintaining, and rebuilding study spaces for all the students, improving quality of life and education.

It involved the development of activities in electricity, carpentry, and painting disciplines by qualified volunteers making it a special opportunity to reunite former students, professors, and young professionals during difficult times in our University. Figure 1 exemplifies some of the activities carried out by volunteers in the specific area of electricity, by the restoration and replacement of luminaries.
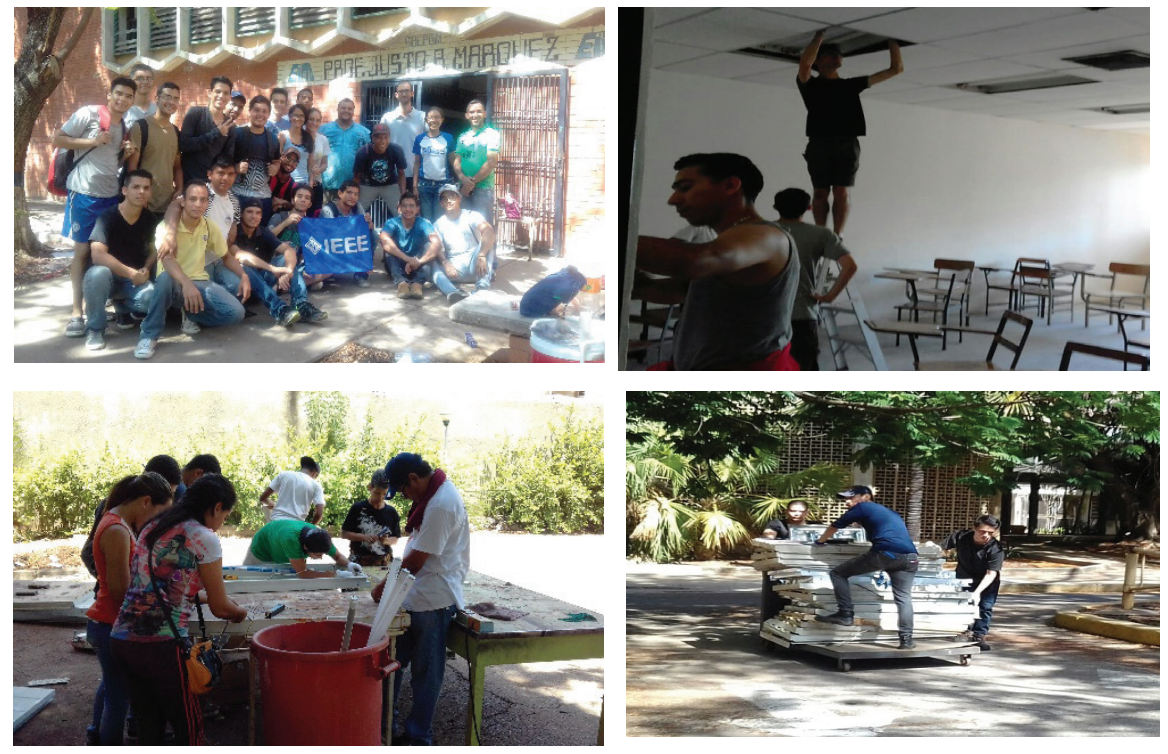

Figura 1. Restoration and replacement of luminaries in the Engineering Faculty of the Universidad del Zulia as part of the "Una mano por tu Facultad" project. 


\section{Distance education program adapted to COVID-19 for Universidad del Zulia}

COVID-19 restrictions have worsened the already critical socio-economic situation of Venezuela. This project aims to develop a distance education program for students of electrical engineering of the Universidad del Zulia (LUZ), located in Maracaibo, Zulia State, which is one of the cities of Venezuela that has been more affected by the complex humanitarian crisis that has taken place in this country. Universidad del Zulia is one of the main universities in the state, but the current situation has impeded access to economic resources and the deterioration of its infrastructure has been evident. Therefore, the project intends to provide internet service and the appropriate electronic equipment for the implementation of an online program for the School of Electrical Engineering.

The launch of the project is possible thanks to funding opportunities offered to special project calls for proposals focused on COVID-19 [6]. This project is aligned with No Poverty, Good Health and Well-Being, and Reduced Inequalities as per United Nations Sustainable Development Goals (SDGs) [7].

The opening of virtual classrooms is currently coordinated by SIGHT group volunteer's collaboration with professors at Distance Education Services from Universidad del Zulia (SEDLUZ) where the digital content created by professors must be adapted to low-speed mobile internet connections to ensure that most of the students can have access to it so that the audio and video must be recorded and compressed.

This project will implement existing mobile apps to create and share educational content for the student community at our location. Furthermore, this Project is using open source and result in open-source resources for others to use. Once this pilot program is concluded, SIGHT volunteers from RE-IEEE-LUZ see with enthusiasm extending this project to other areas within Universidad del Zulia, across Venezuela, and even supporting collaboration with other SIGHT groups from Latin America and Caribbean IEEE Region 9.

\section{Results and discussion}

"Una Mano por tu Facultad" initiative was supported by different NGOs and private organizations providing material resources and volunteers. The project resulted in the recuperation of twentysix (26) classrooms and four (4) laboratories in the Engineering Faculty [4].

More recently, The COVID-19 pandemic has affected the world in an unprecedented manner, and as such, HAC/SIGHT is offering a Call for Proposals to support IEEE grassroots humanitarian technology and sustainable development projects that utilize technology to address the COVID19. As a result, \#20-COV-185 project funding was approved, and the project is currently ongoing.

\section{Conclusions and next steps}

SIGHT-LUZ group work done on humanitarian projects has had important results for the Universidad del Zulia and all the students who participate in a free education in their classrooms. It is hoped that these projects can continue to be carried out with greater commitment and scope over time, to provide solutions based on technologies for the development of local communities.

In the future, it is planned to work on projects related to solar energy as a solution to electricity supply failures in the region. Likewise, work will be done on a project to provide training to migrants and people in vulnerable conditions in border areas, in conjunction with established NGOs. 


\section{Acknowledgment}

RE-IEEE-LUZ and the SIGHT-LUZ group thank Chevron Corporation, Polinter, Nabors, Gerenpro, Confurca, and Turagual for sponsoring this project. Also, special thanks to BCM Ingeniería and BRIPCO Engineering \& Services for gathering sponsors for this project, and always tutoring activities of RE-IEEE-LUZ.

For the new ongoing project, funding is possible thanks to HAC/SIGHT from IEEE. Special thanks to Professor Claudio Bustos de SEDLUZ for his active participation during the development of this project.

\section{References}

[1] Universidad del Zulia, "Universidad del Zulia," 2021. [Online]. Available: www.luz.edu.ve [Accessed 2702 2021].

[2] RE-IEEE-LUZ, "Nuestra Historia," 2019. [Online]. Available: https://site.ieee.org/sb-luzias/nosotros/nuestrahistorial [Accessed 2702 2021].

[3] Arias-Méndez, Esteban \& Xie-Li, Danny, 2021. IEEE en el TEC. Contribuyendo con el avance de la ciencia y la tecnología para el beneficio de la humanidad. Investiga TEC - Enero 2021.

[4] The UN Refugee Agency, "Venezuela Humanitarian Crisis," 2021. [Online]. Available: https:/www.unrefugees. org/emergencies/venezuelal [Accessed 2802 2021].

[5] RE-IEEE-LUZ, "Una Mano por tu Facultad," 2019. [Online]. Available: https://site.ieee.org/sb-luzias/2019/07/24/ una-mano-por-tu-facultad [Accessed 2802 2021].

[6] IEEE, "IEEE HAC/SIGHT Projects Call for Proposals Focused on COVID-19 Response," 2021. [Online]. Available: https://hac.ieee.org/funding-opportunities/covid-19-projects/ [Accessed 2502 2021].

[7] United Nations, "Sustainable Development Goals," 2021. [Online]. Available: https://www.un.org/sustainabledevelopment/sustainable-development-goals/ [Accessed 2502 2021]. 


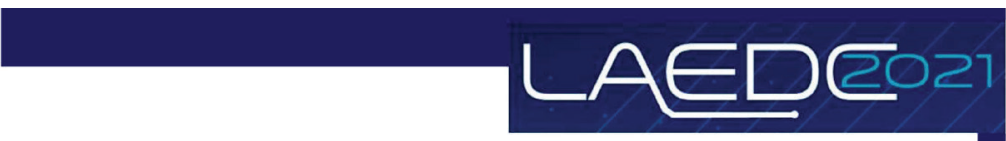

\section{Humanitarian Projects Development from Universidad del Zulia SIGHT Affinity Group}

Luis Rodríguez ${ }^{a}$, Javier Hernández ${ }^{a}$, Javier Peres ${ }^{a}$, José Viloria ${ }^{a}$, Laura Sáncheza, Henry Urdaneta ${ }^{a}$, Douglimar Gonzáleza, Nardiz Mendoza ${ }^{a}$ Josimar Tello-Maitab, Andry Contreras ${ }^{b}$, Manuel Briceñob, and Claudia Guevarac

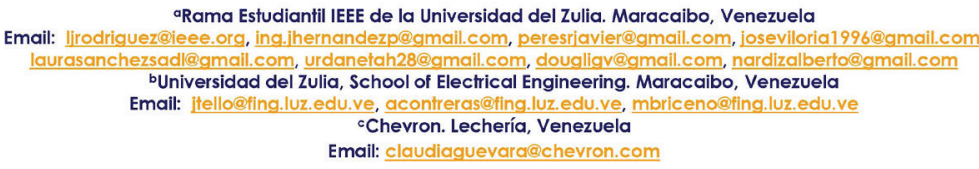

\section{Introduction}

The Universidad del Zulia (LUZ) is one of the largest and most relevant universities from Venezuela, with more than 70.000 students and 150 academic programs. Since 1999 students and professors of the Electrical Engineering School of this institution have

integrated the IEEE student branch (RE-IEEE-LUZ).
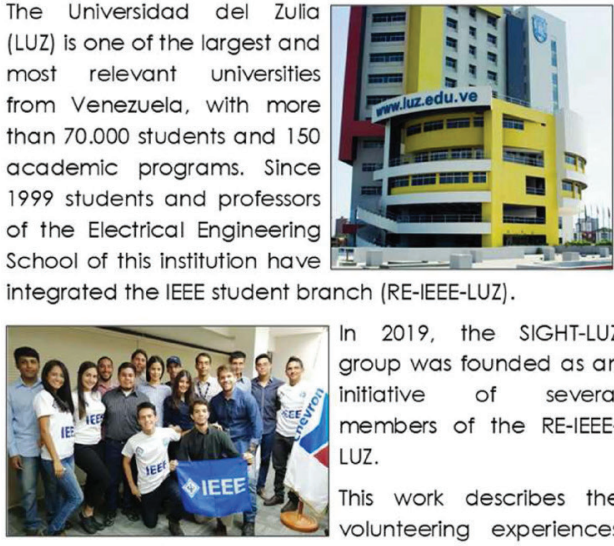

volunteering experiences within humanitarian projects development from SIGHT-LUZ affinity group at Maracaibo, Venezuela.

\section{Materials and Methods}

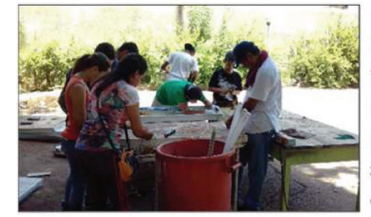

A helping hand for your Faculty, "Una Mano por tu Facultad" was the name given to this project involving all student and professors community from the

Engineering Faculty of Universidad del Zulia.

It involved development activities in electricity, carpentry, painting disciplines by qualified volunteers making it a specia opportunity to reunite

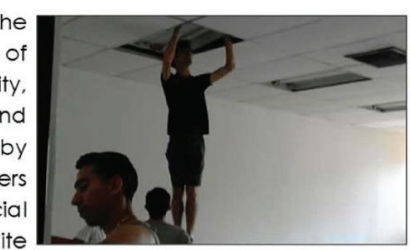

former students, professors, and young professionals during difficult times in our University.

\section{Results and Discussion}

\begin{abstract}
"Una Mano por tu by different NGOs and private organizations providing material resources and volunteers. The project resulted in the recuperation of 26 classrooms ar the Engineering Faculty. RE-IEEE-LUZ and the SIGHT-LUZ group thank Chevron Corporation, Polinter, Nabors, Gerenpro, Confurca, and Turagual for sponsoring this project. Also, special thanks to BCM Ingenieria and BRIPCO Engineering \& Services for gathering sponsors for this project, and always tutoring activities of RE-IEEE-LUZ.

More recently, The COVID-19 pandemic has affected the world in an unprecedented manner, and as such, HAC/SIGHT is offering a Call for Proposals to support IEEE grassroots humanitarian technology and sustainable development projects that utilize technology to address the COVID-19. As a result, \#20-CoV-185 project funding was approved and the project is currently ongoing.
\end{abstract}

\section{Conclusions / Next Steps}

"Distance Education Program Adapted to COVD-19 for Universidad del Zulia", in collaboration with professors a Distance Education Services from Universidad del Zulia (SEDLUZ), will implement existing mobile apps to create and share educational content for the student community at our location. Furthermore, this content will be open access and available for the public in general to use.

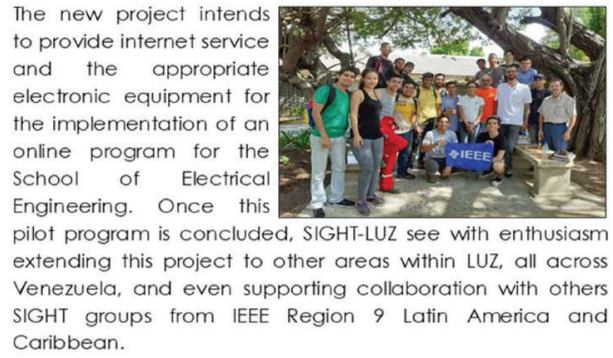
Caribbean.

\section{।IEEE} for Humanity
for Techoly
2021 IEEE Latin American Electron Devices Conference (LAEDC)

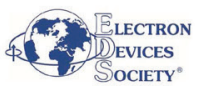

